\title{
Leveraging the Pension Industry for Sustained Economic Growth and Development in Nigeria through Targeted Investments
}

\author{
Peter Imouokhome \\ University of Lagos, Nigeria
}

\begin{abstract}
Research Aim/Problem: Investment of pension funds has overly been limited to a few instruments under the direction of the regulator - PENCOM. This has in effect reduced the effectiveness and ability to make contributions to the needed areas of the real economy of Nigeria. This paper gives players, investors, employers, and employees, regulators, academics, and the entire public, in-depth and all-encompassing insight into the Pension industry and how funds can best be channeled taking into consideration today's macroeconomic exigencies to ultimately benefit all and sundry.
\end{abstract}

Abstract: The Nigerian pension industry has been in existence for over seventeen years with the first established promulgation of the pension law coming into force in 2004. The 2014 Pension reform Act has however repealed the provisions of the erstwhile law helping to establish a well-regulated industry.

The resilience and magnitude of current pension funds notwithstanding, there is still a largely untapped market which gives some signs of a huge prospect in this industry. It is projected that the pension industry will lead the growth of the Nigerian economy for the next decades if more attention is paid to a targeted investment of funds in the real sector and in instruments that promise increased returns for contributors employees even in the face of high inflation and prevalent currency depreciation.

Keywords: 'Investment', 'Pension Funds', 'PENCOM', 'Employers', 'Employees', 'Nigerian', 'Economy', 'Macroeconomic', 'Infrastructure', 'Contributory scheme', 'Real Economy', 'Custodians', 'Administrators'

\section{INTRODUCTION}

$\mathrm{I}^{\mathrm{n}}$ $\mathrm{n}$ retrospect, it is widely attested that an active pension ecosystem effectively congregating players- a regulator, administrators, custodians, public and private sector employers and working-class persons across several age groupsis well established in Nigeria. The maturity of this industryrelative to more advanced economies of the world like the US or the OECD nonetheless, the pension industry globally has displayed great resilience, navigating the turbulence and whirlwinds - the macroeconomic shocks, economic downturns, recession, and more recently a global pandemic in the year 2020 which instigated a fold-down of companies, job losses and a sharp drop in macroeconomic numbers and indices. In spite of periods of passive economic activities, the pension industry has over timeconsistently helped in mobilizing the much-needed funds - more notably from the middle-income segmentof the economy for propelling growth.

According to the National Pension Commission (2020, p. 45), at the end of 2020 - the same year the covid-19 pandemic severely raged resulting intwo-quarters of negative economic growth, pension assets in Nigeria grew to N12.3 trillion. This amount represents $8 \%$ of Nigeria's nominal GDP. There were only a handful of industries thatput up asimilarlystellar performance for the financial year. More recently, $\operatorname{PENCOM}(2020$, p.12 ) also noted that RSA registrations from inception hit 9,383,204 as of 30 June 2021. This was marked by growth from 9,300,058 recorded in Q1: 2021. Overall, the cumulative pension contributions from inception to the end of the second quarter of 2021 amounted to N7.10 trillion.

While these numbers look impressive ata cursory glance, theynevertheless do not paint the true picture of the capacity of the sector. This is because only $11 \%$ of the total workingclass population is active in Nigeria's contributory pension scheme. This is a low penetration rate in comparison to $19 \%$ in South Africa and $77 \%$ in the United Kingdom. (Odutola, 2021) We could only imagine the huge funds that could be mobilized for investment and by effect - growth if coverage couldextend to just half of the working-class population in Nigeria. By all means, it also portends that there is a huge prospect in this industry with a foreseeable ability to lead the quest for sustained economic growth in Nigeria; delivering from the two major policy instruments available to government - the fiscal and monetary policyends of the divide.I am certain that the Pension industry if well nurtured is poised to rank as one of the next three big sectors to lead growth and development in the Nigerian economy in the next twodecades alongside manufacturing and agriculture.

Investment of pension funds has overly been limited to a few instruments under the direction of the regulator - PENCOM. This has in effect reduced the effectiveness and ability to make contributions to the needed areas of the real economy of Nigeria. This paper gives players, investors, employers, and employees, regulators, academics, and the entire public, indepth and all-encompassing insight into the Pension industry and how funds can best be channeled taking into consideration today's macroeconomic exigencies to ultimately benefit all and sundry. 


\section{Extending Pension Coverage and Compliance}

\section{Extending Pension Coverage}

Up from 2004 when the first Pension Act was promulgated, there are now 22 total Pension Fund Administrators (PFA), 6 Closed Pension Fund Administrators (CPFA), and 4 Pension Fund Custodians (PFC) in Nigeria. (PENCOM. 2020). With the Pension Reform Act of 2014 - which repealed the provisions of the 2004 Act - clearly distilling the roles of each playerincluding the reception of contributions, custody, investment, and regulation, there is now a well-detailedgo-to rule of engagement in the industry. The goals have always hovered around the safe custody of pension assets, inclusiveness of contributors, compliance with best practices, risk management, and economic growth.

However, there is a need for a buoyant pension system that is tuned with the ever-dynamic macroeconomic environment. The case for a more flexible system in line with the demands of the immediate financial market and economic environment is sought.

Foremost among the challenges bedeviling the industry has been low coverage and compliance by employers including state governments who also are part of the scheme as detailed by Section 2 of the Public Reform Act 2014 which stipulates that the Pensions Reform Act applies to any employment in the public service of the federation, the public service of the Federal Capital Territory, the public service of the states, the Public service of the Local Government and the Private sector. For private-sector employees, section 2(2) of it shall apply to employees who are in the employment of an organization in which there are 15 or more employees.

The allowance for the fund's mobilization in the contributory pension scheme is well stated In section 4 of the pension reform Act - a total of $18 \%$ of the monthly emolument is to be paid into the Retirement Savings Account (RSAs) of an employee with 'a minimum of $10 \%$ borne by the employer and a minimum of $8 \%$ by the employee'.

\subsection{Compliance}

It is sad to note that compliance withthese provisions and guidelines by the public and private sectors have been low. At theend of 2020, only Lagos, Ondo, and FCT were in full compliance with their state laws pertaining to pensions. (PENCOM, 2020. P.35) A host of other states have found comfort in operating morbid "pay as you go" system. This is also aside from the millions of informal sector employees shut out of the scheme within the private sector.

Awareness, knowledge, and education of the workings of the pension system especially by employees and beneficiaries are still at the lowest ebb. Ideally, the regulators, custodians, and administrators are to lead a worthy charge for sensitization across both the formal and informal sectors.

While strict enforcement of the pension reform Actas a means to exponentially increase the funds mobilized has been consistently advanced by economic analysts, the mode of enforcement and penalty for erring companies and players is critical. At the very least, regulatorsshould immediately consider a synchronization of pension funds enforcement with the country's national identity management system and the review of enforcement at the point of annual financial returns by companies and industries alike.

\section{INVESTMENT OF PENSION FUNDS}

As with the mobilization of contribution from employers and employees alike, the PensionReform Act grants allowance for the investment of such funds to enable owners - employees, and custodians to earn returns on them.

A prominent question to ask is "what drives the allocation and investment of Pension Funds by Custodians and Administrators?" I have discovered that over several climes, Risk, Return, and Cost of funds take prominence among the key considerations in the investment of pension funds. Others include diversification, risk management, hedge against inflation, andliquidity.

According to Q2:2021 figures released by PENCOM, the 4 largest instruments where total pension assets of N12.66 trillion were invested are the Federal Government securities (66\%), Local Money market Securities (13.72\%), Corporate debt securities (7.51\%), and Domestic ordinary shares $(6.66 \%)$ in that order. (PENCOM, 2021. P.18) The FGN bonds took a large chunk of percentage investment in Federal Government securities while Bank placements accounted for the greatest share of the local Money Market Securities.

While it is acknowledged that such distribution will provide the needed funds for infrastructural projects by the government and the funds for corporate growth, they also raise pertinent questions as to the sustainability and impact of such investments on the economic growth and the quality of life of Nigerians.

The Bond market has in fact continued posting persistent total unrealized losses in the RSA Active portfolio. Though this decrease was much lesser during Q2:2021as bonds in the Funds' Marked-to-Market (MTM) portfolio depreciated by a lower sum of N18.33 billion compared to a depreciation of N89.63 billion in Q1: 2021, (PENCOM, 2021 P.22) the depreciation in bond prices register than the goal of greater returns on investment is equally as important as diversification or lower risk threshold.

It can be argued that the investment apparatus set up by the regulator - PENCOM constrains the Pension Fund Administrators to invest the pension funds in the real economy to boost immediate economic growth and development. The National Pension Commission (PENCOM) has a strict percentage of funds under management (FUMS) to be invested in various sectors, markets, or financial instruments. The goal in doing this was to guide against unreasonable risk-taking by Administrators that will result in the impairment of investors' funds. 
It is thus not surprising that as of June 2021, instruments like Real estate properties, Private Equity Funds, and Infrastructure funds took up only $1.23 \%, 0.27 \%$, and $0.53 \%$ respectively of the total pension assets invested. (PENCOM, 2021 P.22)

This activity in the Nigerian pension industry is at variance with emerging trends in the global pension industry where the shift has now been towards allocation of capital to alternative investments - specifically to commodities, high-yield bonds, hedge funds, real estate, and private equity.Portfolios of assetbacked securities, e.g., student loans are now tools used by pension funds to increase returns same way private equity investments arebecoming popular and making a grand incursion into the pension industry.

\section{USING PENSION FUNDS TO STEER ECONOMIC GROWTH AND DEVELOPMENT}

Nigeria's level of pension assets to GDP is only a little over 8 percent while in developed markets, they surpass the $100 \%$ mark. (ThisDay Live, 2020) UK had a pension to GDP ratio of 118.5 in 2020. (OECD. 2021. P.2)

There is thus a need for the Nigerian Pension industry to consider non-traditional avenues of investment - in particular - alternatives and infrastructures in line with global trends.

Investments in infrastructure are more targeted at the real sector of the economy with a direct impact on transportation, power, utilities, renewable energy, communication, social welfare, and institutions, like schools and hospitals.

This is even necessary given that the Nigerian financial and money market has been hit by record low-interest rates in the past year. TB rates, in particular, have hovered around $2.5 \%$ over the past 4 quarters representing a dip from the over $10 \%$ plus rates obtainable in the year 2018. (National Bureau of Statistics. 2021)It is projected that diversification into new investment sources will help to manage risks, negative returns, and marketfluctuationssubsisting in the volatile equity and fixed income markets in Nigeria.

Investments in long-term infrastructure funds poise higher returns than a shorter investment in equity or fixed income buoyed by the fact that pension funds have a constant level of inflow. The investments made by the PFAs should be subject to the prevailing exchange and inflation rate in the country. It will defeat the purpose if people save to cater for livelihood during old age, yet these funds that have been saved are not sufficient to cater for retirement.

Investments in alternatives like infrastructure will help manage the high inflation levels currently in operation in the Nigerian economy. These investments are less sensitive to the risk of inflationand do not fluctuate unnecessarily, deepening investment to create impact.

PFAs can invest directly in projects and so help with effective tracking of the capital that is dedicated by institutional investors. Investment in crowdfunding activities is at their highest levels. Pension funds can take advantage of such opportunities to make long-lastingtechnology-driven financial and social services in the economy with a high rate assured. Investing directly in infrastructure that givescapital to the real sectors and industries in the Nigerian economy will also increase production of local exportable goods and raw materials, increase foreign exchange earnings, and in turn stem the tide of the depreciation of the Naira.

With this, there will be a focus on an increase in per capita income and not a nominal economic growth that is unevenly distributed and skewed. This is important because the prevailing rate of inflation in Nigeria will mean that contributory pension funds at retirements will be unable to cater to the needs of retirees after years of dedicated input over productive years of work-life into an RSA. In Section 16(1) of the pension reform Act, it is stated that an employee is not entitled to make any withdrawal from his retirement savings account before attaining the age of 50 years. It is thus safe to say that if an employee does not lose his job or does not stayunemployed for a minimum of 4 months in order to access $25 \%$ of his contributed pension fund (as stipulated by the Pension Reform Act) it means that access to pension funds are shut out of contributors over their working years till retirement.

This obvious shortchange of beneficiaries can only be prevented and addressed with an increased rate of return or a rebased growth (by GDP inflator) that takes into cognizance the inflation rate - a 'real economic growth in economic parlance.

Inasmuch as the contributions of the federal government to the retirement benefit of employees of the public service remains a charge of the consolidated revenue fund of the Federation as directed by the Pension Reform Act, there will continually be a strain on the income of the government and so targeted investments are necessary.

In terms of geographical biases, there is a need for the national Pension commission to grant allowance to pension administrators to diversify their holdings from domestic to foreigninstruments. While at the risk of capital flights, more benefits accrue from such a portfolio given the current currency fluctuations, high inflation, and uncertainty in the domestic capital and money markets. Overseas investments have been known to effective control currency fluctuations. However, care should be taken that these funds are invested in stable markets and that they are made upon a strongasset management advisory services.

It was discovered that there were

\section{CONCLUSION}

In all these, the regulatory body should provide the much needed allowance, monitoring, supervision and guidance for the diversification of funds while ensuring that pension administrators are guided by the strong governance, process and, transparency. Goals of equitable distribution of income, 
good healthcare, education, and climate change, will be effectively advanced with a well-functioning pension system.

Finally, that the contributory scheme is primarily set up for the payment of retirement benefit should not portend that it cannot be expanded to ensure that financial services that are concomitant to its mission are offered especially while trying to deepen the inclusion of the informal sector into the scheme through the adoption of mobile money and the collaboration with Telcos and financial players that are closer to the rural population aside other operational strategies like the Micro Pension Plan (MPP)

\section{BIBLIOGRAPHY}

[1] National Bureau of Statistics (2021) 2021 Statistical Bulletin

[2] National Pension Commission (2014) Pension Reform Act
[3] National Pension Commission (2020) Approved 2020 Annual Report. Nigeria. P.45. P.29. p.35

[4] National Pension Commission (2021) Second Quarter Report. Nigeria. P.12. P.18. P.22

[5] OECD (2021) Pension Funds in Figure. P.2

[6] Sajo, I. and Li, B. (2017) Financial Development, Export and Economic Growth in Nigeria. Theoretical Economics Letters, 7, 2239-2254. doi: 10.4236/tel.2017.77153.

[7] Wale Odutola, Low Pension Penetration At $11 \%$ Worries Contributory Pension Scheme (CPS) Operators. 2021.

\section{AUTHOR}

Peter Imouokhome is an Economist and development expert who works with BusinessDay Media Limited as a Senior Economic Analyst. 